\title{
USAGES RELATING TO WINE: NUNC EST BIBENDUM
}

LES USAGES RELATIFS AU VIN:

NUNCEST BIBENDUM 


\title{
USAGES RELATING TO WINE: NUNC EST BIBENDUM
}

\author{
LES USAGES RELATIFS AU VIN: \\ NUNC EST BIBENDUM
}

\author{
PIERRE MOUSSERON \\ Professor at the Faculté de Droit de Montpellier ${ }^{*}$ \\ President of the Institut des usages \\ https://www.umontpellier.fr/recherche/unites-de-recherche/centre-du-droit-de-lentreprise \\ p.mousseron@wanadoo.fr
}

\begin{abstract}
Defined as practices with legal force, usages are the issue of a debate relating to the definition of the most relevant sources of law. This debate is particularly lively in the agro-food sector.

The first part of the article examines the presence of many usages in the production, the marketing as well as the consumption of wine.

In a more dynamic perspective, the second part shows a marginalization of regional usages and the vitality of the transnational usages.

This situation invites to defend, in the third part, regional usages in order to promote legal diversity. This promotion highlights a new protective effect of usages concerning traditional practices restricted by certain "appellations d'origine controlee" or "protégée".
\end{abstract}

Keywords: usages, sources of law, customary law

Résumé: Définis comme des pratiques dotées d'une force juridique, les usages sont l'enjeu d'un débat tenant à la définition des sources du droit les plus appropriées. Ce débat est particulièrement vif dans le secteur agro alimentaire.

La première partie de l'article examine la présence de nombreux usages aussi bien dans l'élaboration, la commercialisation que la consommation du vin.

Dans une perspective plus dynamique, la seconde partie témoigne d'une marginalisation des usages régionaux et de la vitalité des usages transnationaux.

Cette situation invite à défendre, dans une troisième partie, les usages régionaux afin de promouvoir une diversité juridique. Cette promotion met en lumière un nouvel effet des usages protecteur de pratiques traditionnelles malmenées par certaines appellations d'origine contrôlée ou protégée.

mots-clés: usages du vin, sources du droit, droit coutumier

\footnotetext{
* This article was thought out and written in honor of Professor George DAWSON, Professor at the university of Florida. The author would like to thank Mr. Michel Ampeau (Domaine Robert Ampeau \& Fils, Meursault), Ms. Béatrice de Chabert and Ms. Valérie Roux (Syndicat AOC Languedoc), Mr. Mickael Diore (Restaurant Le Grillardin, Montpellier), Mr. Alain Grignon (Société LGI Wines, Carcassonne), Mr. Karl Buhler and Mr. Nicolas Melmer (Students in the International Business Law Master program at the University of Montpellier School of Law, class of 2013), Ms. Valérie Maillot (Division Lactalis AOC) and the Jean-Pierre Rambier family (Domaine du Haut Lirou, Saint-Jean de Cuculles) for their precious help.
} 
Wine has long been associated with a number of rites, whether they be Dionysian feasts ${ }^{2}$, bacchanalia or the Last Supper.

These rites associated with wine are particularly active in the world of trade 3 .

These rites are not all usages seen here as behaviors having a legal force due to certain qualities such as repetition and legitimacy. The fact that we toast before drinking is thus more a social practice rather than a legal practice. Some of these usages associated with wine do however have legal force. These occur especially in the assessment of the responsibility of the different actors of the wine market or in the ability to consume wine in certain places.

The study of the usages of wine under French law is not (just) a regional interest. The usages are today at the heart of a strategic issue related to the building of the rule of law. Should we give the monopoly of legal rules in the matter to rules coming from above, and in particular from the European Union, or should we make a place for rules which come from individuals themselves?

This debate is vital for certain professionals in the agricultural sector. Many producers of cheese, foie gras and traditional products are now subject to an ever increasing European regulatory pressure. In the wine sector, the debate arose in the media in 2009 after an attempt by the European Commission to accept that rosé wine be obtained by mixing (blending) white wine and red wine. Before the general outcry of the producers of rosé wine from the south of Europe, on June 8, 2009 the Commission finally maintained the prohibition of blending ${ }^{4}$. The tension between the national and European authorities is still strong in this sector. It is particularly noticeable in the context of the transformation of the former national Appellations of Controlled Origin (AOC) to Appellations of Protected Origin (AOP) and Geographically Protected Origin (IGP) which are governed at the European level. The French national federation of producers of crémant thus brought an action before the French Administrative Supreme in order to obtain the annulment of 36 ministerial orders allowing the granting of new IGP in this sector. This professional federation especially regrets that "most of the wine regions can now claim this IGP without arguing any right of priority or usage..."

The issue is also important for law professionals. In the same way that the nationalization of the law during the French Revolution has sounded the death knell of certain regional customary courts, that the Europeanization has marginalized some legal disciplines such as

2 H. Johnson, Une histoire mondiale du vin, de l'Antiquité à nos jours, Hachette 1989, p.49 et s.

3 Let's mention the example of the former practice of the «pot-de-vin » which refers in the subject of a lease to " an additional amount added to the price agreed upon for rent and which is paid by the renter to the owner”; A. Sayag and J. Hilaire, Quel droit des affaires pour demain? Essai de prospective juridique. Librairies Techniques 1984, p. 218.

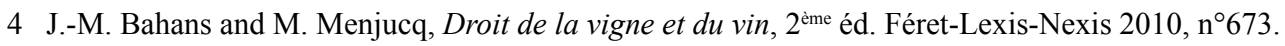

5 Response of the Ministry of agriculture, agro-food industry and forestry of 13 December $2012, \mathrm{n}^{\circ} 01841$. 
domestic competition law, the current globalization weakens the rules of the national States. This globalization changes the context and the usefulness of usages. As the rules of the market become more global, the economic operators rely more on transnational commercial practices such as Incoterms detached from local practices. Simultaneously and conversely, a need to return to local realities mobilizes the recourse to local usages.

After observing some usages relating to wine (I), we can analyze their evolution (II) and consider their protection (III).

\section{Observation of usages relating to wine.}

One can observe usages at the time of production (A), marketing (B) and consumption (C) of wine.

A. Usages in the production of wine

\section{Usages in grape cultivation}

Contracts for the sale of vine plants usually consist of purchase orders and delivery, which due to their brevity, leave room for many usages. Amongst these, our interlocutors have notably described for us that which leads the nurseryman vendor to replace the vine plants that have not taken within one year of planting.

The intervention of the pickers also leaves room for usages. The first is the use of fixed term contracts. The use of this exceptional form of employment contract is authorized by article L.1242-2-3 $3^{\circ}$ of the French labor code which defines the exhaustive list of cases in which an employer may resort to this type of contract. This text cites the "seasonal type jobs or jobs for which...it is a continuing usage not to use a long term employment contract due to the temporary nature and character of the activity". Furthermore, the peculiarity of the pickers' working conditions leads to many usages related to different means of remuneration. Only a few years ago, the pickers received two or three liters of wine per harvest day in addition to a cash payment. The usage of this payment in kind was substituted by an additional cash payment. Usages also affect the working time. In Burgundy for instance, it is a usage not to pay the pickers for rainy days. The Harvest-type contract proposed by the Mutualité Sociale Agricole confirms this usage. It states that the contract is concluded "for no specific time period, that is to say that the contract will be terminated with the attainment of the objective: the end of the harvest."

\section{Usages in winemaking}

Winemaking processes rely heavily on non-written traditions such as fermentation, blending and aging procedures which make each wine unique.

Some of these processes can have a legal value when the winemaker will have agreed 
to them within the context of specifications. However in this case it will not be a usage as long as the obligation to respect these processes will not stem from the behaviors themselves but from the commitment to respect them. One will be in the presence of a usage when the specifications will refer to usages. Such is the case in the specifications of the appellation of controlled origin "Languedoc" approved by the decree $n^{\circ} 2011-1508$ dated 10 November 2011 which states that "the wines are vinified according to the local, loyal and constant usages". One will also be in the presence of a usage when the process becomes binding in the absence of any outside commitment. This is for example the case of a winemaker who will be forced to maintain a process such as aging in oak barrels once his buyers will have become accustomed to this technique.

A. Usages in the marketing of wine

\section{Labeling}

Labeling displays regional peculiarities. The term "cru" does not have the same meaning according to the region. In the region of Bordeaux, it refers to a classification of vineyards whereas in Burgundy, Champagne and Alsace, it corresponds to a terroir classification ${ }^{6}$.

\section{Sale}

The sale of wine abides by particular usages. Some are general. Article 1857 of the French Civil Code states "for wine, oil and other things that we have a usage of tasting prior to purchase, there is no sale until the buyer has tasted and approved". Professional buyers often come to taste wine as early as November, just two or three months after the harvest. This practice is observed by French as well as foreign buyers. The approval occurs differently depending on whether the sale is in bulk or for bottles. In the latter case, the tasting by the broker does not qualify as approval ${ }^{7}$. Other usages are specific to the sale of certain wines. Regarding primeur wines, the Court of appeal of Paris referred to usages to rule that a delivery was late. Concerning wines that are still being vinified by the winemaker at the time of the order, the court considered that a delivery period of three years was customary according to usages ${ }^{8}$.

Incidental to the sale, there is the usage by most winemakers and wine merchants to deliver the bottles free of charge ("gratuitées") to business partners. This practice has legal force in that it should allow to justify to tax authorities the non-sale of a number of bottles produced or purchased.

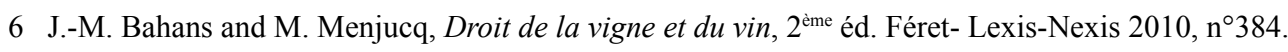

7 CA Bordeaux 27 avril 2004, D. 2005.155.

8 CA Paris Pôle 4, chambre 9, 28 June 2012, n¹1/15128, Foellner c. Société 1855.
} 


\section{Distribution}

Marketing methods vary across regions. In certain regions such as Bordeaux or Burgundy, marketing wine has long been entrusted to brokers. The seniority of these relations is conducive to the establishment of usages. Thus, the Court of cassation ruled that " the establishment and sending by the broker to the seller and the buyer of the letter of confirmation without a formal agreement on their part was equivalent, according to an old and constant usage in the Bordeaux region, to a perfect sale, except protest within in a very short period set out by the loyal and constant usages of the profession within 48 hours of receipt of this letter of which the broker has the responsibility of sending." usages of Bordeaux impose on the broker in addition to his duty of introducing the parties, an obligation to assist the buyer particularly during the approval. These usual obligations do not go as far as making the broker reliable in the case of default of payment by the seller ${ }^{10}$. The parties are deemed to have chosen the usages of the place where they operate ${ }^{11}$. Here we are only referring to a particular application of article 1159 of the French Civil Code according to which "That which is ambiguous is interpreted by what is of usage in the country where the contract is entered into".

In the Languedoc region, the majority of the production is entrusted to cooperative cellars. The relations within each cooperative give rise to particular usages relating especially to the date of transfer of ownership of the grapes or to the means of remuneration.

In other regions, the marketing is rather by merchant traders, buyers-dealers. In sales thus negotiated, it is usual to specify that the wines will be «loyal marketable quality $»^{12}$. The professionals that we met have indicated that the fair characteristic referred to compliance with the sample and that the marketable characteristic referred more to the absence of oxidation, earthy taste or acidity.

To avoid having a margin taken by these intermediaries, some winemakers work directly with distributors. In the direct relations that they have with the distributors, these winemakers sometimes invoke article L. $442-6, \mathrm{I}, 5^{\circ}$ of the French Commercial Code which punishes the rupture of established trade relations not complying with the notice periods set out in particular by usages. In a situation of this kind, the Court of appeal of Versailles dismissed the operator of a winery. It held that in giving this operator in January a notice for the end of the annual seasonal period, that is to say the end of summer 2008, the Monoprix

\footnotetext{
9 Cass. com. 13 May 2003, $n^{\circ} 00-21555$.

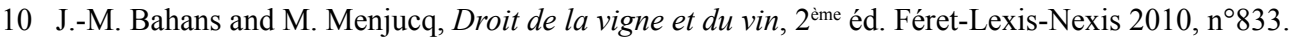

$11 \mathrm{Ph}$. Guez, Contrat de courtage, Juris Classeur Contrats-Distribution, Fasc. 850, n³8. In this direction: CA Bordeaux 25 May 2010, n09-01653.
}

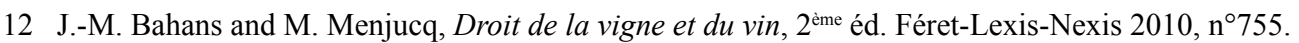


vending company had complied with sufficient notice with regards to usages and the duration of the business relationship which was of six years in this case ${ }^{13}$.

B. Usages in the consumption of wine

\section{Content of usages linked to wine consumption}

For a long time, religious and civil authorities have been concerned with limiting wine consumption in the fight against drunkenness and alcoholism. Facing these limitations, usages play a role in neutralizing religious and legal guidelines. Moderate alcohol use is thus accepted in a number of Islamic countries.

The private consumption of wine by winegrowers is the opportunity for a customs usage which allows winegrowers to exclude from the tax base the excise tax of a certain number of bottles which are destined for personal consumption. Questioned by one of our interviewers, a customs agent however avoided determining the amount of bottles exempt from this tax. Beyond this reluctance, the computerization of customs formalities could put an end to this customary tolerance.

The usage of replacing corked or insufficiently filled bottles benefits the customer over the restaurant owner and the restaurant owner over their supplier (wine merchant or producer).

\section{Force of usages linked to wine consumption}

Usages linked to wine consumption illustrate the diversity of legal force that usages can receive.

A violation of the rules of wine tasting is only an error of lack of taste which has more a social rather than a legal impact. The barrier between these two worlds however is not impenetrable. An inelegant behavior during a business lunch such as directly offering wine to a Muslim ${ }^{14}$ can have significant legal consequences such as the failure of negotiations.

Consumption usages sometimes influence the authorities themselves. How otherwise explain that article R. 4228-20 of the Labor Code which sets out "No alcoholic beverages other than wine, beer, cider and perry are allowed in the workplace." Even if the judge does not refer to them, there are also usages that can explain the decision of the Conseil d'Etat to invalidate the provision of internal procedure of the French subsidiary of an American company prohibiting "the consumption of alcoholic beverages in the company"15.

Observing behavior in the development, marketing and consumption of wine has allowed us to identify a number of usages. In a more synthetic and dynamic approach, we can now examine their evolution.

\footnotetext{
13 CA Versailles $12^{\text {ème }}$ ch., 3 July 2012, n ${ }^{\circ}$ 10-08577, Escarelle SA c. Monoprix (SA).

14 One can however leave wine at his disposal...

15 Conseil d'Etat $1^{\text {st }}$ and $6^{\text {th }}$ met sections, 12 November $2012, \mathrm{n}^{\circ} 349365$.
} 


\section{Evolution of usages relating to wine}

As we witness a marginalization of regional usages (A), we simultaneously observe a strong resistance of transnational usages (B).

\section{A. Marginalization of regional usages}

\section{Maintaining regional usages}

Private relations between wine professionals fall within many regional usages. Membership in the Professional Union of Champagne wine brokers thus assumes adhering to an ethical charter aimed "to clarify certain usages within the profession". This charter provides inter alia a ban to act against the decisions taken by the disciplinary committee of the Union. It is not unreasonable to think that the promotion of these usages thus aims to organize a certain protection for established professionals.

The resistance of regional usages is sometimes driven by strong localism. While advertising for wine is strictly regulated as to limit alcoholism, article L.3323-2 of the Public Health Code still tolerates ads "in favor of festivals and traditional fairs devoted to local alcoholic beverages" ${ }^{\prime 16}$. This article illustrates the tension between a modern public health objective of the legislature and an ancient tradition for festive events in wine country.

\section{Opposing European law}

In their effort to put into place a harmonized agricultural system, the European institutions are the main forces of opposition to regional usages.

There is opposition at the conceptual level. French law bases rights related to controlled appellations on "a law resulting from usages" 17 . The administration only "recognizes" a preexisting law. For its part, the European community law imposes a "request for protection" on the part of the wine growers which suggests that the law does not pre-exist.

The 2006 Agreement between the European Community and the United States of America for the trade of wine is also symptomatic of this approach. To define the beverages covered by the agreement, this treaty mentions "good enological practices". This substitution of a system no longer referring to old practices, usages, but to new practices is characteristic of a desire to take over the regulation of a market by the European authorities.

We observe a similar phenomenon of marginalization of usages with labeling. Article 118, paragraph 12 of European Regulation 491/2009 of 25 May 2009 limits the traditional

16 The control of the constitutionality of this law was the opportunity for the constitutional council to affirm that this provision was not contrary to the principal of equality before the law in the sense that the legislator can settle differently different situations or break away from equality for reasons of general interest (Dec. n $90-283$ DC of 8 January 1991).

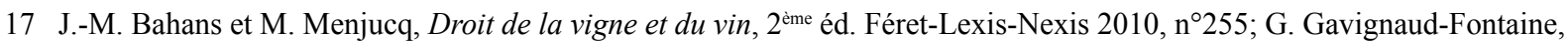
Terroirs et marchés des vins dans un siècle de crises, 2011, Presses universitaires de la Méditerranée, p. 38. This author observes : "Yesterday, usages were the rule, today this is typicalness which makes the terroir ». 
terms that can figure on the labels ${ }^{18}$. In addition, it states that "traditional terms are listed, defined and protected by the Commission". ${ }^{19}$

\section{A. Resisting transnational usages}

As for other commodities, the international wine trade allowed for the modernization of techniques. The bag-in-box upgraded packaging by bottle as the barrels had

in the past improved the amphorae. The screw cap is also gradually replacing the cork stopper as it had replaced the frosted glass stopper in the 19 th century ${ }^{20}$. In the future, the global development of wine machines serving wine like beer on tap will promote the sale of wine in bulk and will limit the sale of bottles. This influence of international trade techniques rubs off on legal techniques. The standard contracts for the sale of wine in bulk used in international matters largely influence the contractual practice.

The success of international fairs dedicated to wine such as VINEXPO contributes to a standardization of the behavior of the merchants. Thus the Incoterms developed by the International Chamber of Commerce and qualified as usages by the Court of Justice of the European Union ${ }^{21}$ are frequently used for wine. This is explained in particular by the high risk of wine bottles breaking which calls for specific stipulations like the Incoterms relating to risk. If producers prefer "Ex Works, départ Propriété" sales, the use of the Incoterm CIF (Cost Insurance Freight) is the most common towards China. Despite the delay in the transfer of property, it allows French merchants to avoid incurring high Chinese importation taxes.

The complexity of national written law in this context is particularly favorable to this customary development. This explains that article 9 of the Vienna Convention on the international sale of goods refers to usages. This also justifies that article 1511; paragraph 2 of the French Civil Procedure Code provides that the arbitrator in an international arbitration "takes into account, in all cases, trade usages".

The development of transnational usages should put an end to many regional usages relating to wine. This result raises the question of protection for certain wine usages.

\section{Protection of usages relating to wine}

\footnotetext{
18 This article 118; paragraph 12 states : " A 'traditional term' is a term used in a traditional manner in a member State for products referred to in article 118 bis, paragraph $1:$ a) to indicate that a product benefits from an appellation of protected origin or an indication of geographical protection under Community or national law; or b) to describe the method of production or aging or the quality, color, type of place or a particular event linked to the history of the product benefitting from the appellation of controlled origin or an indication of geographical protection. 2.

19 Decree $n^{\circ} 2012-655$ dated 4 May 2012 limits these regional particularities.

20 H. Johnson, Une histoire mondiale du vin, de l'Antiquité à nos jours, Hachette 1989, p. 195.

21 CJUE 9 June 2011, ElectroSteel Europe SA c.Edil Centro SpA., Aff. 87/10. The qualification of usages of Incoterms is questionable insofar as these terms derive more strength from the reference to the rules of the ICC than from their repetition (P. Mousseron, Faut-il dissocier les usages du commerce international des usages du commerce?, RJCom. 2011, p. 21).
} 
The programmed disappearance of certain regional usages calls to question the possibility (A) and the means (B) of their protection.

\section{A. Interest of protecting wine usages}

Consumer protection is often emphasized in order to limit the role of usages. This is particularly the case in the harmonization of the means of wine production or the fight against alcoholism. This argument however presents limitations to personal freedom.

Another line of justification for these violations of usages relates to economic efficiency. Harmonized European regulations would guarantee better legibility and a greater efficiency for producers. This argument is certainly justified for major producers. It also however knows its limits. On the one hand, attempts at standardization seem futile. Texts can hardly recognize the diversity of man and his willingness to stand out ${ }^{22}$. Thus, the effort to standardize the terms appearing on the labels is constantly being falsified by new terms to be controlled. The control of certain terms such as the phrase "veilles vignes" (old vines) could more simply and coherently be a matter of unfair competition law rather than European Union law. On the other hand, European regulations today lead to a puff pastry of rules which are particularly illegible for the producers themselves who have lost their local contacts able to quickly advise on regulations relevant to them.

Promoting usages is recommended for the maintenance of our legal diversity. This diversity is not an end in itself. The standardization of the rules is even positive in terms of economic efficiency. On the other hand, the standardization of services and products induced by the standardization of the rules is disturbing. There is standardization in the wine sector. Thus, some producers must enter into a real administrative battle in order to change the specifications of certain appellations in order to continue using traditional but rare grape varieties.

B. Means of protecting wine usages

\section{Content of legal argument}

The defense of wine usages could rely on several legal arguments.

Concerning the usages relating to the production of wine, European Union law $a$ priori seems unfavorable to the defense of legal diversity. This is not surprising given its primarily economic goal. As shown in the position of the prosecuting attorney in the seeds case $^{23}$, however this situation could evolve. The European regulations limiting the diversity of marketable seeds indeed affect "the principal of proportionality, the freedom of enterprise

22 As Portalis wrote in 1801 in his preliminary discourse to the first draft of the civil code: "As son as a code, as complete as it may seem, is completed, thousands of unexpected issues come before the judges. Because once drafted, laws remain as they were written. Men, on the contrary, never rest...Many things are therefore necessarily abandoned to the empire of usages, to the discussion of educated men, to the arbitration of judges».

23 CJUE 12 July 2012, Aff. C-59/11, Association Kokopelli c. Graines Baumaux SAS ; J. Huet, La guerre des semences 
within the meaning of article 16 of the Charter of fundamental rights of the European Union, the free circulation of goods within the meaning of article 34 TFUE and the principal of equal treatment within the meaning of article 20 of said Charter".

In addition it is arguable that the marginalization of usages affects the rule of subsidiarity laid down by article 5 of the European Union Treaty ${ }^{24}$.

Finally, the effect of attraction on consumers by the usual manufacturing methods could allow professionals to invoke a right to property on these intangible assets ${ }^{25}$. This stretch of the right to property could particularly rely on the jurisprudence of the European Court of Human Rights of Strasbourg ${ }^{26}$. The French Administrative Supreme Court has thus referred to the European convention for the protection of human rights and fundamental liberties and its first additional protocol concerning the protection of the right to property to cancel a decree limiting the customary rights of beneficiaries of the appellation "Pomerol" 27 . And indeed, the winemaking practices associated with a territory grant customary rights that can help to challenge legal acts aiming to implement the European appellations of controlled origin. Customary protection seems at least as convincing as one based on appellations established by a frequently questionable scientific link between a product and a terroir. The discussion is especially possible when the geological qualities of a terroir greatly vary within the same appellation ${ }^{28}$.

Concerning usages relating to the consumption of wine, the Convention for the safeguard of cultural heritage signed in 2003 and which entered into force in 2006 testifies to international legal protection of certain good usages. Among the customary social practices protected by this convention, UNESCO had indeed recognized in 2010 the "gastronomic meal of the French" which is characterized by a harmonious marriage between food and wine.

\section{Implementation of legal argument}

The promotion of usages would require the active intervention of wine professionals.

continue..., RLDA December 2012, p. 71.

24 Article 5 of the European Union Treaty states: «Under the principle of subsidiarity, in areas which are not within its exclusive competence, the European Union intervenes only if and to the extent where the objectives of the proposed action cannot be achieved sufficiently by the Member States, both at central and at regional and local level, but can be better, due to the size or the effects of the proposed action, at the level of the European Union ».

25 This argument appears as a watermark in the 16 May 2000 decision by the CJUE in the case of la Rioja (Belgium v. Spain, C-388/95). In this case, the CJUE justified a Spanish rule prescribing an on-site bottling of a certain type of wine despite the infringement of the free circulation of goods. To justify this ruling, the court mentioned the "reputation" which comes from this

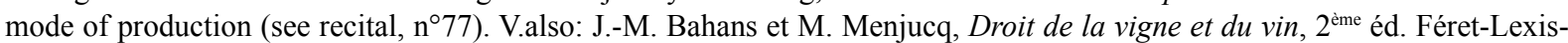
Nexis $2010, \mathrm{n}^{\circ} 769$.

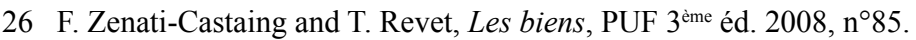

27 Conseil d'Etat, 9 Mar. 2012 (3rd and 8th combined sub-sections, 334575, published in the recueil Lebon) rescinding the decree $n^{\circ}$ 2009-1237 of 14 October 2009 approving the provisions of the specification of the AOC « Pomerol».

28 For an illustration: J.-C. Bousquet, Terroirs viticoles, Paysages et géologie en Languedoc, Editions Ecologistes de l'Euzière, 2011, sp., p. 165. See also for an illustration of the insufficiency of the European regime of area names: TPIUE April 23, 2018, T. 43/15, Piadina Romagnola. 
Yet sometimes they seem to abandon these usages and especially the one which is provided for in the French Civil Code according to which it is customary that the sale of wine should intervene only at the tasting. The following clause may be read in the sale conditions of a Burgundy wine producer: "By way of derogation from the provisions of article 1857 of the Civil Code, the sale is closed without prior tasting". The usage of prior tasting is also pushed aside when it comes to very expensive wines. These disregards however further illustrate the rather residual nature of usages as the general negation of this type of regulation. Wine professionals could win by creating standard contracts or at least models for non-binding contracts. This is already the case in some areas. The Inter-professional Council of Bordeaux Wines has thus established a standard contract for sale in bulk and another for the sale by bottle. These contracts allow in particular to specify the date the contract was established in the event of an intervention of a broker. They are so recognized that their provisions shall apply even when the buyer is not established in the Bordeaux region. ${ }^{29}$

The promotion of usages also depends on legal professionals. As early as law school, legal studies should incorporate them more. Today the minds of students are indeed far too often formatted for the purpose of finding and applying rules of public origin. This method discredits legal services and lawyers. Lawyers' roles are not only to passively participate in applying the law which comes from above. It is also their duty to more actively participate in defining the rules of law by incorporating original private sources into their work.

In this latter role, it is time for lawyers to drink to the source of usages.

\section{References}

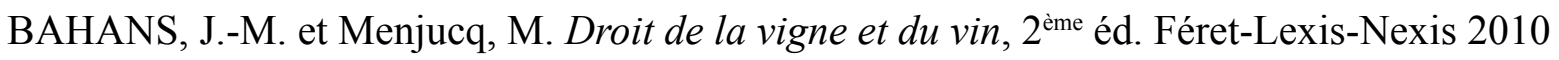
BOUSQUET, J.-C. Terroirs viticoles, Paysages et géologie en Languedoc, Editions Ecologistes de l'Euzière, 2011.

CA Bordeaux 27 avril 2004, D. 2005.155.

CA Bordeaux 25 mai 2010, n$^{\circ} 09-01653$.

CA Paris Pôle 4, chambre 9, 28 juin 2012, n¹1/15128, Foellner c. Société 1855.

CA Versailles $12^{\text {ème }}$ ch., 3 juillet 2012, n 10-08577, Escarelle SA c. Monoprix (SA).

CASS. COM. 13 mai 2003, n00-21555.

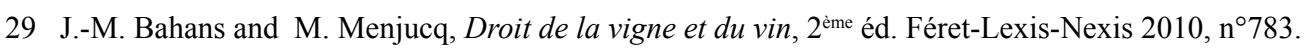


CJUE 12 juillet 2012, Aff. C-59/11, Association Kokopelli c. Graines Baumaux SAS

CJUE 9 juin 2011, ElectroSteel Europe SA c.Edil Centro SpA., Aff. 87/10.

TPIUE April 23, 2018, T. 43/15, Piadina Romagnola.

Conseil d'Etat $1^{\text {ère }}$ et $6^{\text {ème }}$ sous sections réunies, 12 novembre $2012, n^{\circ} 349365$.

Conseil d'Etat, 9 mars 2012 (3ème et 8ème sous-sections réunies, 334575, publié au recueil Lebon)

Decree $n^{\circ} 2012-655$ du 4 mai 2012

Decreee $\mathrm{n}^{\circ} 90-283$ DC du 8 janvier 1991

GAVIGNAUD-FONTAINE, G. Terroirs et marchés des vins dans un siècle de crises, 2011, Presses universitaires de la Méditerranée.

GUEZ, Ph. Contrat de courtage, Juris Classeur Contrats-Distribution, Fasc. 850, n³8.

HUET, J. La guerre des semences continue..., RLDA décembre 2012.

JOHNSON, H. Une histoire mondiale du vin, de l'Antiquité à nos jours, Hachette 1989.

MOUSSERON, P. Faut-il dissocier les usages du commerce international des usages du commerce ?, RJCom. 2011.

PORTALIS, Jean-Étienne-Marie. Discours préliminaire au premier projet de code civil, 1801.

REPONSE DU MINISTERE DE L'AGRICULTURE, DE L'AGROALIMENTAIRE ET DE LA FORET du 13 décembre 2012, n01841.

SAYAG, A. et HILAIRE, J. Quel droit des affaires pour demain? Essai de prospective juridique. Librairies Techniques 1984.

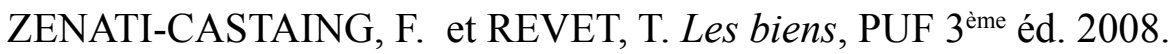

\section{SOBRE O AUTOR:}

\section{Pierre Mousseron}

Professor of Law, University of Montpellier, Law School (France). Co-Director

Centre du Droit de l'Entreprise. Director of the Master Program Droit du Commerce International (International Business Law Program), University of Montpellier. Senior Fellow, Center for International Financial Crimes Studies, University of Florida. Director of the Program Business Law Summer School, University of Montpellier. Director of the Program Certificat de spécialisation en Droit des sociétés, University of Montpellier.

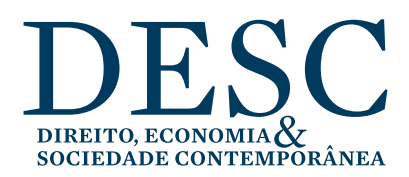

